\title{
Research Paper: Evaluation of the Relationship Be- tween Fine Motor Skills and Demographic Indices in Students With Hearing Impairment
}

\author{
Saideh Sadat Mortazavi ${ }^{1}$, Zahra Mortazavi $^{2 *}$, Sedigheh Sadat Mirbagheri ${ }^{1}$ \\ 1. Department of Occupational Therapy, School of Rehabilitation Sciences, Hamedan University of Medical Sciences, Hamedan, Iran \\ 2. Department of Speech Therapy, University of Social Welfare and Rehabilitation Sciences, Tehran, Iran.
}

Citation: Mortazavi SS, Mortazavi Z, Mirbagheri SS. Evaluation of the Relationship Between Fine Motor Skills and Demographic Indices in Students With Hearing Impairment. Physical Treatments. 2016; 6(2):93-102. https://doi.org/10.18869/nrip.ptj.6.2.93

: https://doi.org/10.18869/nrip.ptj.6.2.93

Article info:

Received: 30 Nov. 2015

Accepted: 23 Mar. 2016

Keywords:

Fine motor skill,

Demographic indexes,

Hearing impaired student

\begin{abstract}
A B S T RA C T
Purpose: Human hands, thanks to their fine movements, are efficient tools to work, play, and do daily life activities, especially in students with specific requirements such as the ones with hearing impairment.

Methods: Thirty-two students (14 males and 18 females) with hearing impairment with the mean age of 8.43 years participated in the current research. The present descriptive-analytical study was conducted in a cross-sectional format using convenience sampling method. The research tools included demographic questionnaire, the Conners scale, and Purdue pegboard test. The data were analyzed by SPSS 23 , and the results were evaluated based on mean value comparison tests for 2 groups ( 2 independent samples T-Test), and also more than 2 groups (ANOVA).

Results: Average (SD) scores of different parameters were obtained as follows: speed of dominant hand, 6.67(1.20); speed of non-dominant hand, 4.81(1.42); coordination of hands, 1.34(2.96); hand skill, 14.48(3.64), and assembly, 8.26(5.31). Gender, handedness, and cause of hearing impairment did not play a significant role in the acquired scores of the hand skills $(\mathrm{P}>005)$. Average scores of both hands' skill was significantly different between the rural and urban groups $(\mathrm{P}=0.013)$, and the average score acquired for hand skill in the rural group was higher than that of the urban group. Also, concerning the relationship between the parents' education and hand skill, a significant relationship was observed between the mothers' education and the students' hand skills $(\mathrm{P}=0.006)$.

Conclusion: The effects of mothers' education and living place on fine motor movement were more significant than the other causes such as hearing impairment, handedness, and gender. Therefore, the necessity of rehabilitation and instructional interventions of fine (delicate) hand movements is emphasized for hand performance improvement in daily life activities, education, as well as ambient and recreational experiences.
\end{abstract}

\footnotetext{
* Corresponding Author:

Zahra Mortazavi, PhD

Address: Department of Speech Therapy, University of Social Welfare and Rehabilitation Sciences, Tehran, Iran

Phone: +98 (918) 8381571

E-mail: zmortazavi.st@gmail.com
} 


\section{Introduction}

H

earing impairment is a common sensory problem in human societies and nearly 360 million people are affected worldwide. Prevalence of mild to severe congenital hearing impairment is estimated as 2 to 4 babies per 1000 births in most developed countries [1]. In Iran, the prevalence of severe to deep hearing impairment is estimated as 1 to 3 babies per 1000 births [2,3]. Hearing disorders lead to other disorders, but the relationship between physical disorders and hearing impairments is confirmed [4-7]. Perhaps one of the major reasons for the importance of motor skills is its crucial role in performing different aspects of daily life activities [8]. With their complicated structure, human hands are efficient organs and a significant tool to interact with the environment and serve as means of doing work, playing, and performing daily life activities by their delicate and fine movements [8]. Fine motor skills are the integral part of motor skills [9] and their impairment might cause fundamental problems, which worsen as the people grow up and more get involve in the community. This impairment simply keeps people away from what they deserve [10].

Besides depending on the impairment degree, the person will lose the chance of acquiring sensory information and effective experiences from the environment $[8$, $11,12]$. This important fact causes problems, particularly for activities [13] related to school, such as writing [14], reading skills, cognitive functions [15], and educational achievement $[16,17]$. Scientific evidence indicates that children with hearing disorder hesitate in nonverbal aspects, including motor evolution [7]. The motor evolution is necessary to comprehend and interact with external world, including educational skills and school [11]. The importance of hand movements in students with hearing impairment can be also viewed from another point of view such as computer application in education system.

Multimedia technology is a modern and diverse method to transfer concepts and information within various frameworks [images, different voices, animations, and videos), which guarantees diversity and continuity of learning along with deploying different senses of learners, and this is especially significant in students with hearing impairment, because it mainly makes the visual perception involved and does not remarkably require the auditory power; of course the prerequisite is that the students should have the ability to use the computer mouse and keyboard, which need fine hand movements [18]. However, some studies, including Dummer reported the impairment of hand movement [19], and Petruse report- ed the impaired dexterity [20] in the group of children with hearing disorders compared to the normal group. Nevertheless, research on delicate movements of students with hearing impairment is rare. The current study aimed to analyze the relationship between fine skills and demographic indexes (gender, handedness, hearing impairment causes, parents' education, and living place) in students with hearing impairment.

\section{Materials and Methods}

In the preliminary analysis, the study was conducted on 45 students with hearing impairment, aged 7 to 11 years, and studying in the schools of Hamadan City, Iran in the academic year 2015-2016. Four cases were excluded from the study due to gaining scores above 34 in the Conners test, 6 due to lack of parents' collaboration, 3 because of mental retardation, and 1 for having diplegic cerebral palsy. Finally, 32 students with hearing impairment (14 males and 18 females) with the mean age of 8.43 years, ranged from 91 to 137 months, were enrolled in the study. The mean (SD) time of using hearing aid was $0.09 \pm 1.32$ years, varied from 4 to 10 years; $56 \%$ of the participants were monolingual and $44 \%$ bilingual.

The current descriptive-analytical study was conducted in a cross-sectional design. The samples were taken from students with hearing impairment by means of convenience sampling method. Upon approval of the Ethics Committee of Hamadan University of Medical Sciences and Exceptional Students Education Office, and completion of informed consent forms by the students' parents, preliminary analysis was done using demographic questionnaire (age, gender, year of entry to the school, educational level, living place, parents' educational level, dominant hand, causes of hearing impairment, disease history, and hearing aid usage) and attention-deficit hyperactivity disorder on localized version of the Conners scale. In the last stage, fine motor skill was evaluated by Purdue pegboard test as a reliable test to analyze motor skills of hands [21,22], and test reliability was approved with an average to high rating [23].

Inclusion criteria of the study comprised: 1) Completion of consent forms by the students' parents; 2) $\mathrm{Ab}$ sence of neurological diseases and hand orthopedics; 3 ) Absence of stress and anxiety; 4) Lack of distraction; 5) Age 7 to 11 years, based on the birth certificate; 6) Hearing testing evaluation in the previous year; 7) Audiometry result of over $70 \mathrm{~dB} \mathrm{HL}$ (severe to profound hearing impairment). Exclusion criteria of the study were as follows: 1) failure in collaboration during the study, and 2) inability to perform each of the test stages. 


\section{Purdue Pegboard Test}

It is a test to evaluate fine motor skill of both hands $[24,25]$. The test repeatability is reported 0.6 to 0.76 for one trial and 0.91 for an average of 3 trials [26, 27]. It consists of the following subtests:

Movement speed of dominant hand: It is scored based on the number of pegs taken by the dominant hand from the vessel on the side of the same hand. The examinee starts with the upper hole and puts each peg inside a row on the side of the dominant hand within 30 seconds.

Movement speed of non-dominant hand: It is scored based on the number of pegs taken by the non-dominant hand from the vessel on the side of the same hand. The examinee starts with the upper hole and puts each peg inside a row on the side of the non-dominant hand within 30 seconds.

Both hands (bimanual coordination): To evaluate bimanual coordination, the examinee takes pegs from vessels in the right and left sides and starts the test. The examinee has 30 seconds to put the pegs in 2 rows of pegboard holes. Each peg pair placed inside the holes is counted as a score.

Hand skill: It means the sum of the movement speed scores of the dominant plus non-dominant hand plus both hands.

Assembly: Number of pegs, collars, and washers put inside the holes within 60 seconds is regarded as the criterion [28].

\section{The Conners Scale}

The current study employed the customized Conners questionnaire (26 questions for parents). The respective questionnaire is a convenient screening tool to seek for probably ill children (higher score of the Conners scale means higher likelihood of attention-deficit hyperactivity disorder) [29], and also to measure the intensity of attention-deficit hyperactivity disorder symptoms. Conners et al. reported reliability of the respective scale as 0.9 . Validity of this questionnaire was reported 0.85 by the Institute of Cognitive Sciences. Average score of 1.5 or above suggest the presence of attention-deficit hyperactivity disorder. In other words, the respective scale has 26 questions, and thus, the total score ranges from 26 to 104. A child's score exceeding 34 represents attentiondeficit disorder. Higher scores signify greater level of disorder and vice versa. The Conners scale is scored using a 4-option Likert-type scale [30].
The data acquired from the questionnaire were transferred into SPSS version 23 for analysis. Statistical indexes (mean value, standard deviation, etc.) were employed to describe the research sample characteristics. With regard to statistical analysis, comparison of mean values test ( 2 independent samples T-Test) was employed to compare the 2 mean values of the 2 independent groups of observations; for example males and females, and analysis of variance (ANOVA) was used to compare the mean values of more than 2 groups, for instance with regard to different levels of father's education.

\section{Results}

The Kolmogorov-Smirnov test was applied to measure normality of data distribution, and normality assumption holds for all research variables in the students with hearing impairment. Based on the evaluation made by Purdue pegboard test, the following average (SD) values were obtained: dominant hand, 6.67(1.20); non-dominant hand, 4.81(1.42); both hands, 2.96(1.34); hand skill,14.48(3.64); and assembly, 8.26(5.31). Comparative results of the acquired scores from fine hand movement skill in righthanded and left-handed students did not suggest any significant difference $(\mathrm{P}>0.05)$. The results also showed no significant difference between the research variables in the 2 groups of males and females $(\mathrm{P}=0.42)$ (Table 1$)$.

The cause of hearing impairment was congenital in 31 (96.9\%) cases and acquired in 1 case due to high bilirubin. Among the congenital causes of hearing impairment, 21 cases had the history of hearing impairment in the close relatives, 5 cases were idiopathic, and 5 persons reported marriage with close relatives without the history of family hearing impairment. ANOVA results of comparing speeds of dominant and non-dominant hands, both hands, and hand skill, and assembly in students based on the cause of hearing impairment in the society suggest the fact that scores of dominant and non-dominant hand speeds, bimanual coordination, hand skill and assembly were not significantly different based on the cause of hearing impairment $(\mathrm{P}=0.30)$ (Table 2). The results also demonstrated that the mean value of hand skill had significant difference between 2 groups of rural and urban examinees $(\mathrm{P}<0.05)$, and the mean value obtained for the rural group was greater than that of the urban one (Table 1).

Results of ANOVA test to compare the movement speed of dominant and non-dominant hands, both hands, and assembly in students based on the fathers' educational level in the group of students with hearing impairment indicated that the average score of the tests acquired by the students whose fathers had different levels of educa- 
tion (1. uneducated; only with reading and writing ability, 2. high school diploma, and 3. Academic education) were not significantly different (hearing impaired group: $\mathrm{P}=0.21$ ) (Table 2).

However, the result was significantly different regarding mothers' educational levels. The results revealed a significant difference between hand skill of the students and mothers' low level of education compared to the group with the education level of high-school diploma and higher $(\mathrm{P}<0.05)$ (Table 1$)$. Among the 32 cases under study, the mean hearing losses of right and left ears were 85-90 dB HL and 90-95 dB HL, respectively. In one of the cases, hearing impairment was fluctuating and moderate and severe hearing losses were recorded in audiometric tests. Most of the respective children had incomprehensible speech. Communication method was reported as body language in $50 \%$ of examinees and general communication for the other $50 \%$.

The examinees received 2.5 years of preschool rehabilitation (speech and language therapy: $34.4 \%$, auditory education: $25 \%$, simultaneous speech therapy, auditory education: $31.3 \%$, and simultaneous speech therapy, auditory education, and occupational therapy: 9.4\%).

\section{Discussion}

The current study aimed at analyzing the relationship of fine skill and gender, handedness, causes of hearing impairment, parent's education, and the living place of students with hearing impairment. The current study at- tempted to exclude noticeable cognitive disorder out of the sample population. Accordingly, 3 mentally retarded students were excluded from the study based on the health certificate and school entry evaluation test. Additionally, previous studies such as Pastor et al. reported that emotional and behavioral disorders are widely prevalent among children and often leave negative consequences on the educational performance, social relationships, and their growth [31]. Children and adolescents with hearing impairments are more likely to develop behavioral problems [32]. A significant relationship was found between attention-deficit disorder and disorder in fine movements $[33,34]$. Therefore, the students with noticeable cognitive disorder, including attention and concentration deficit (4 cases) were also excluded from the study based on the Conners rating scale.

In the present research, mean value of hand skill subtests improved with increasing age in alignment with the research conducted by Mirzakhani et al., which emphasized that hand skill would improve with increasing age [35]. Comparative results of the current research demonstrated that gender did not play an effective role in the acquired score of fine skill. According to the results of Jafari et al., no study showed static and dynamic equilibrium in hearing impairment between males and females. Other studies such as the ones by Lindsey and O’Neal, Effgen [36] and Mirzakhani et al. [35] also indicated the same findings. Nonetheless, Nazi et al. stated a significant difference between mean scores of eye and hand coordination in 2 groups of normal males and females of the first year of elementary school, in which the

Table 1. Results of 2 independent samples T-Test comparing dominant and non-dominant hands speeds, both hands, and hand skill, and assembly in the study cases based on gender, living place, and mother's education.

\begin{tabular}{|c|c|c|c|c|c|c|c|c|c|c|c|c|}
\hline \multirow{3}{*}{ Variables } & \multicolumn{4}{|c|}{$\begin{array}{l}\text { Gender of the Students With Hearing } \\
\text { Impairment }\end{array}$} & \multicolumn{4}{|c|}{$\begin{array}{l}\text { Living Place of the Students With Hearing } \\
\text { Impairment }\end{array}$} & \multicolumn{4}{|c|}{$\begin{array}{c}\text { Mothers' Educational Level of the Students } \\
\text { With Hearing Impairment }\end{array}$} \\
\hline & $\begin{array}{c}\text { Fe- } \\
\text { male=18 }\end{array}$ & Male $=14$ & \multirow{2}{*}{$\mathbf{P}$} & \multirow{2}{*}{$\mathbf{T}$} & City $=43$ & Village $=\mathbf{2 1}$ & \multirow{2}{*}{$\mathbf{P}$} & \multirow{2}{*}{$\mathbf{T}$} & Elementary & $\begin{array}{l}\text { High } \\
\text { School }\end{array}$ & \multirow{2}{*}{$\mathbf{P}$} & \multirow{2}{*}{$\mathbf{T}$} \\
\hline & \multicolumn{2}{|c|}{ Mean $\pm S D$} & & & \multicolumn{2}{|c|}{ Mean $\pm S D$} & & & \multicolumn{2}{|c|}{ Mean $\pm S D$} & & \\
\hline $\begin{array}{l}\text { Dominant } \\
\text { hand }\end{array}$ & $\begin{array}{c}6.62 \pm \\
1.38\end{array}$ & $\begin{array}{l}6.86 \pm \\
0.95\end{array}$ & 0.55 & 0.59 & $\begin{array}{c}8.02 \pm \\
2.06\end{array}$ & $\begin{array}{c}9.43 \pm \\
2.18\end{array}$ & 0.015 & $2.510-$ & $\begin{array}{c}46.6 \pm \\
17.1\end{array}$ & $\begin{array}{c}83.7 \pm \\
40.0\end{array}$ & 0.001 & -4.826 \\
\hline $\begin{array}{l}\text { Non- } \\
\text { dominant } \\
\text { hand }\end{array}$ & $\begin{array}{c}4.84 \pm \\
1.50\end{array}$ & $\begin{array}{c}4.86 \pm \\
1.89\end{array}$ & 0.96 & 0.05 & $\begin{array}{c}6.35 \pm \\
2.33\end{array}$ & $\begin{array}{c}7.86 \pm \\
2.29\end{array}$ & 0.017 & 2.447- & $\begin{array}{c}57.4 \pm \\
39.1\end{array}$ & $\begin{array}{c}00.6 \pm \\
89.0\end{array}$ & 0.024 & -2.379 \\
\hline $\begin{array}{l}\text { Both } \\
\text { hands }\end{array}$ & $\begin{array}{l}2.89 \pm \\
1.45\end{array}$ & $\begin{array}{c}3.21 \pm \\
1.18\end{array}$ & 0.50 & 0.68 & $\begin{array}{c}4.70 \pm \\
2.53\end{array}$ & $\begin{array}{l}6.09 \pm \\
2.34 \pm\end{array}$ & 0.038 & $2.124-$ & $\begin{array}{l}80.2 \pm \\
26.1\end{array}$ & $\begin{array}{c}10.4 \pm \\
26.1\end{array}$ & 0.046 & -2.080 \\
\hline Hand skill & $\begin{array}{c}14.00 \pm \\
3.88\end{array}$ & $\begin{array}{c}15.7 \pm \\
3.33\end{array}$ & 0.42 & 0.82 & $\begin{array}{c}18.88 \pm \\
6.73\end{array}$ & $\begin{array}{c}23.48 \pm \\
6.69\end{array}$ & 0.013 & $2.518-$ & $\begin{array}{c}88.13 \pm \\
60.3\end{array}$ & $\begin{array}{c}00.17 \pm \\
75.2\end{array}$ & 0.006 & -2.95 \\
\hline Assembly & $\begin{array}{c}7.78 \pm \\
5.64\end{array}$ & $\begin{array}{c}9.07 \pm \\
4.94\end{array}$ & 0.50 & 0.67 & $\begin{array}{c}11.32 \pm \\
6.47\end{array}$ & $\begin{array}{c}15.48 \pm \\
5.55\end{array}$ & 0.014 & $2.568-$ & $\begin{array}{c}15.7 \pm \\
58.4\end{array}$ & $\begin{array}{c}150.13 \pm \\
46.5\end{array}$ & 0.057 & -0.978 \\
\hline
\end{tabular}

Hand skill is referred to dominant hand plus non-dominant hand plus both hands.

PHYSICAL TREA TMENTS 
Table 2. Results of ANOVA test for $;$ comparing speeds of dominant and non-dominant hands, bimanual coordination, hand skill, and assembly in the study cases based on the cause of hearing impairment and father's education level in the research population.

\begin{tabular}{|c|c|c|c|c|c|c|c|c|c|c|}
\hline \multirow{2}{*}{ Variables } & \multicolumn{5}{|c|}{ Cause of Hearing Impairment in the Students } & \multicolumn{5}{|c|}{$\begin{array}{l}\text { Fathers' Educational Level in the Students With Hearing Impair- } \\
\text { ment }\end{array}$} \\
\hline & $\begin{array}{l}\text { Cause of Hear- } \\
\text { ing Impairment }\end{array}$ & Mean \pm SD & $\begin{array}{l}\text { Std. } \\
\text { Error }\end{array}$ & $\mathbf{F}$ & $\mathbf{P}$ & & Mean $\pm S D$ & $\begin{array}{l}\text { Std. } \\
\text { Error }\end{array}$ & $\mathbf{F}$ & $\mathbf{P}$ \\
\hline \multirow{3}{*}{$\begin{array}{l}\text { Dominant } \\
\text { hand }\end{array}$} & Family history & $6.57 \pm 1.24$ & 0.27 & & & $\begin{array}{l}\text { Elementary } \\
\text { school }\end{array}$ & $6.21 \pm 1.81$ & 0.31 & & \\
\hline & No family history & $7.00 \pm 1.00$ & 0.58 & 0.27 & 0.76 & High school & $7.14 \pm 1.16$ & 0.31 & 2.43 & 0.10 \\
\hline & $\begin{array}{l}\text { Audiopathic } \\
\text { reasons }\end{array}$ & $6.80 \pm 1.30$ & 0.58 & & & $\begin{array}{l}\text { University } \\
\text { degrees }\end{array}$ & $7.00 \pm 0.81$ & 0.40 & & \\
\hline \multirow{3}{*}{$\begin{array}{l}\text { Non-domi- } \\
\text { nant hand }\end{array}$} & Family history & $4.71 \pm 1.55$ & 0.33 & & & $\begin{array}{l}\text { Elementary } \\
\text { school }\end{array}$ & $4.35 \pm 1.27$ & 0.34 & & \\
\hline & No family history & $5.00 \pm 1.41$ & 0.63 & 0.12 & 0.88 & High school & $5.28 \pm 1.58$ & 0.42 & 1.59 & 0.221 \\
\hline & $\begin{array}{l}\text { Audiopathic } \\
\text { reasons }\end{array}$ & $5.00 \pm 1.00$ & 0.44 & & & $\begin{array}{l}\text { University } \\
\text { degrees }\end{array}$ & $5.00 \pm 0.81$ & 0.40 & & \\
\hline \multirow{3}{*}{ Both hand } & Family history & $2.85 \pm 1.42$ & 0.31 & & & $\begin{array}{l}\text { Elementary } \\
\text { school }\end{array}$ & $2.92 \pm 1.26$ & 0.33 & & \\
\hline & No family history & $3.40 \pm 1.14$ & 0.50 & 0.33 & 0.71 & High school & $3.42 \pm 1.39$ & 0.37 & 1.98 & 0.15 \\
\hline & $\begin{array}{l}\text { Audiopathic } \\
\text { reasons }\end{array}$ & $3.00 \pm 1.00$ & 0.50 & & & $\begin{array}{l}\text { University } \\
\text { degrees }\end{array}$ & $2.00 \pm 0.81$ & 0.40 & & \\
\hline \multirow{4}{*}{ Hand skill } & & & & & & $\begin{array}{c}\text { Elementary } \\
\text { school }\end{array}$ & $13.64 \pm 3.65$ & 0.97 & & \\
\hline & Family history & $14.09 \pm 3.93$ & 0.85 & & & High school & $15.50 \pm 3.93$ & 1.05 & & \\
\hline & & & & 1.24 & 0.30 & & & & 1.62 & 0.21 \\
\hline & $\begin{array}{l}\text { No family history } \\
\text { Audiopathic } \\
\text { reasons }\end{array}$ & $14.80 \pm 3.11$ & 1.56 & & & $\begin{array}{l}\text { University } \\
\text { degrees }\end{array}$ & $13.75 \pm 1.70$ & 0.85 & & \\
\hline \multirow{3}{*}{ Assembly } & Family history & $7.33 \pm 5.41$ & 1.18 & & & $\begin{array}{l}\text { Elementary } \\
\text { school }\end{array}$ & $6.78 \pm 4.52$ & 1.20 & & \\
\hline & No family history & $11.20 \pm 2.68$ & 1.20 & 0.43 & 0.65 & High school & $10.21 \pm 5.93$ & 1.58 & & \\
\hline & $\begin{array}{c}\text { Audiopathic } \\
\text { reasons }\end{array}$ & $7.60 \pm 4.39$ & 1.96 & & & $\begin{array}{l}\text { University } \\
\text { degrees }\end{array}$ & $6.78 \pm 4.52$ & 1.20 & & \\
\hline
\end{tabular}

females exhibited a better performance [37]. Sheykh et al. asserted in a research that execution time of hexagon test for females was better than that of males in the comparative study of movement performance parameters of female and male students aged 11 to 16 years, living in the Southern Tehran [38].

Jafari et al. in a study using Edinburgh dexterity scale tool reported the prevalence of left-handedness in normal students and the ones with deafness as $9.7 \%$ and $10 \%$, respectively with no significant difference between the groups $(\mathrm{P}=0.901, \mathrm{z}=0.24)$. In both groups of normal students and the ones with deafness, left-handedness prevalence in males was more than females, but gender and age did not have a significant relationship with handedness [39]. The current study confirmed the prevalence of handedness in the groups.

As a minor objective of the research, analytical results of comparison of fine motor skills in right-handed and left-handed groups suggested no significant statistical difference. To explain the reason, the brain evolution should be considered, because a large region of human's brain cortex is allocated to control hand skill. However, 
in manual activities, 2 hands rarely have the same capability and right-handedness is dominant in most statistical populations [40]. Most subjects in the current study were right-handed too, and considering the fact that most of daily life activities are done with emphasis on one side and the environment does not have any specific selection toward left-handedness or right-handedness, it seems that no difference should be observed regarding the fine motor skill of individuals.

The results of the study also indicated that fine motor skill was not significantly related to the cause of hearing impairment in the students with such problem. Although no study was carried out concerning fine motor skills, the current study results were in agreement with those of Butterfield study in a group with hearing impairment. His studies on movement and balance skills in children with hearing impairment aged 3 to 14 years indicated that the cause of hearing impairment, degree of hearing impairment, and gender did not have any impact on gross motor skills [41].

Another research hypothesis was lack of correlation between fine motor skills and living place of the students. However, findings revealed a significant relationship between the hand skill and living place of the students; the mean values obtained in the examinees indicated superior movement status of rural students that can be attributed to the presence of open space for rural students and existence of different restrictions in urban life environment. The children in urban areas had fewer opportunities for the diverse tests and experience of surrounding environment due to restriction in the surrounding space and inside the house, and even preoccupation of their parents and their absence for long hours. On the other hand, large number of children in these spaces such as kindergartens and absence of suitable space for this purpose lead to a specific decline in acquiring experience and successful accomplishment of activities [42].

In this regard, Tsiotra et al. believed that sociocultural conditions are effective in determining movement skill level of children [43], and greater chance would be available for interactions between children in villages, thanks to the cultural texture and economic and social similarities of individuals. Furthermore, results of the current study match with those of Walhain et al. who confirmed weakness of fine movements of 7-year-old urban children compared to the similar rural group through studying the motor activities, movement coordination, and the activities associated with health in rural and urban children in Surinam [44].
The current study also aimed at analyzing the relationship between parents' educational level and hand skill of the participants and the results suggested the fact that hand skill was significantly related to mother's educational level. The reason might be the close relationship of mother and child, because mother is the main responsible person for the child care and has the maximum relationship all day long [45]. The environment is not a stagnant force to influence all individuals similarly. Based on the theory of dynamic systems, mother's educational level is an ambient factor affecting socioeconomic and cultural status, and the interaction among family members. It is commonly known that adjustment of the selected motor programs has a greater impact compared to routine activities and its principle factors are the chance of exercise, environment enrichment and stimulation, ambient facilities and conditions, and the educational quality [46] realized by the presence of a knowledgeable mother. Mandemakers et al. believed that the reason for positive effect of mother's education level was the higher level of awareness and the possibility of creating a safe environment and further welfare in this area [47].

Positive correlation of mother's educational level and progress [48], as well as the duration devoted to doing activities have been confirmed in normal students [49]. Furthermore, a relationship was confirmed among mother's educational level, reduction of behavioral problems, and enhancement of social skills in children with specific requirements [46]. Mirzakhani et al. did not observe a significant correlation between components of father's education level and fine motor skills in a research work aimed at instructing fine hand movements and its impact on the progress of drawing skill of slow-learner group [35]. Rosblad and Gard conducted a study on comparing Swedish and American children and concluded that Swedish children had a significant superiority over American ones with regard to skills of playing the ball [50].

All the examinees in the present research had the same nationality and ethnicity. It is preferable to assess the association of the individuals' ethnicity (Fars, Turk, Kurd, and Lor) with fine hand movements. However, it was not possible to analyze the effect of ethnicity on fine motor skills in the current study due to small number of accessible samples. Lack of access to more qualified subjects for the study was one of the limitations of the present study and the future researchers are recommended to include more samples in their studies.

Based on the study results, the impacts of environmental factors, including mother's educational level and living place on fine hand movement skills of the students 
with hearing impairment are more significant than factors such as the cause of hearing impairment, handedness, and gender. Thus, we suggest that medical and instructional interventions of students with hearing impairment be incorporated in rehabilitation programs of the respective children to promote fine motor skills of hand and improve hand performance and its fine movements in different scopes of routine life activities (education, playing, and leisure).

\section{Acknowledgements}

The current paper was part of a research project ratified by Hamadan University of Medical Sciences (Registration code: 9305212533), accomplished with collaboration of respectable management of Exceptional Students Education Organization in 2015. The authors hereby appreciate the cooperation of authorities involved, as well as the dear families and teachers who helped carry out the research.

\section{Conflict of Interest}

The authors declared no conflict of interests.

\section{References}

[1] Shemesh R. Hearing impairment: Definitions, assessment and Management. In: Stone JH, Blouin M, editors. International Encyclopedia of Rehabilitation. New York: Springer Publishing; 2010.

[2] Karmakar NC, Kalansuriya P, Azim RE, Koswatta R. Chipless radio frequency identification reader signal processing. Philadelphia: Wiley-Blackwell; 2016. doi: 10.1002/9781119215783

[3] Zaman-Pour MS, Hatami-Zadeh N, Vameghi R, Bakhshi E. [Assistive technology needs assessment from adolescent students with hearing loss and their parents, Ahvaz City2013 (Persian)]. Journal of Rehabilitation. 2015; 15[4):42-51.

[4] Rajendran V, Roy FG, Jeevanantham D. Effect of exercise intervention on vestibular related impairments in hearingimpaired children. Alexandria Journal of Medicine. 2013; 49(1):7-12. doi: 10.1016/j.ajme.2012.10.001

[5] Rine RM, Cornwall G, Can K, Locascio C, O'hare T, Robinson E, et al. Evidence of progressive delay of motor development in children with sensorineural hearing loss and concurrent vestibular dysfunction. Perceptual and Motor Skills. 2000; 90(3):1101-12. doi: 10.2466/ Pms.2000.90.3c.1101

[6] Lewis S, Higham L, Cherry DB. Development of an exercise program to improve the static and dynamic balance of profoundly hearing-impaired children. American Annals of the Deaf. 1985; 130(4):278-84. doi: 10.1353/ aad.2012.1020
[7] Rajendran V, Roy FG, Jeevanantham D. Postural control, motor skills, and health-related quality of life in children with hearing impairment: A systematic review. European Archives of Oto-Rhino-Laryngology. 2011; 269(4):1063-71. doi: 10.1007/s00405-011-1815-4

[8] Case-Smith J, O'Brien JC. Occupational therapy for children. $6^{\text {th }}$ ed. Maryland: Elsevier Health Sciences; 2013.

[9] Smith YA. Normative and validation studies of the nine-hole peg test with children. Perceptual and Motor Skills. Sage Publications. 2000; 90(3):823. doi:10.2466/ pms.90.3.823-843

[10] Moreira RS, Magalhães LC, Alves CRL. [Effect of preterm birth on motor development, behavior, and school performance of school-age children: A systematic review (Português)]. Jornal de Pediatria. 2014; 90(2):119-34. doi: 10.1016/j.jpedp.2013.05.009

[11] Case-Smith J. Effects of occupational therapy services on fine motor and functional performance in preschool children. American Journal of Occupational Therapy. 2000; 54(4):372-80. doi: 10.5014/ajot.54.4.372.

[12] Hertling D, Kessler RM. Management of common musculoskeletal disorders: Physical therapy principles and methods. Philadelphia: Lippincott Williams \& Wilkins; 2006.

[13] Henderson A, Pehoski C. Hand function in the child Foundations for remediation. Philadelphia: Mosby; 2006.

[14] Hunter SJ, Donders J. Pediatric neuropsychological intervention. Cambridge: Cambridge University Press; 2007. doi: $10.1017 /$ cbo9780511545894

[15] Case-Smith J. Fine motor outcomes in preschool children who receive occupational therapy services. American Journal of Occupational Therapy. 1996: 50(1):52-61. doi: 10.5014/ajot.50.1.52

[16] Jepsen RH, Vonthaden K. The effect of cognitive education on the performance of students with neurological developmental disabilities. NeuroRehabilitation. 2002; 17(3):201-209.

[17] Hartman E, Houwen S, Visscher C. Motor skill performance and sports participation in deaf elementary school children. Adapted Physical Activity Quarterly. 2011; 28(2):132-145. doi: 10.1123/apaq.28.2.132

[18] Kirk S, Gallagher JJ, Coleman MR, Anastasiow NJ. Educating exceptional children. Boston: Cengage Learning; 2011.

[19] Dummer GM, Haubenstricker JL, Stewart DA. Motor skill performances of children who are deaf. Adapted Physical Activity Quarterly. 1996; 13(4):400-14. doi: 10.1123/ apaq.13.4.400

[20] Petrou S, McCann D, Law CM, Watkin PM, Worsfold S, Kennedy CR. Health status and health-related quality of life preference-based outcomes of children who are aged 7 to 9 years and have bilateral permanent childhood hearing impairment. Pediatrics. 2007; 120(5):1044-52. doi: 10.1542/ peds.2007-0159

[21] Callahan AD, Hunter JM, Mackin E. Rehabilitation of the hand: surgery and therapy. St. Louis: Mosby; 1995. 
[22] Ghamari N, Rafiei S, Soltani R, Ghamari Z. [Effect of perceptual motor interventions on dexterity of mentally retarded children (Persian)]. Koomesh. 2016; 17(3):570-579.

[23] Wilson BC, Wilson JJ, Iacoviello JM, Risucci D. Purdue pegboard performance of normal preschool children. Journal of Clinical Neuropsychology. 1982; 4(1):19-26. doi: 10.1080/01688638208401113

[24] Rafiee S, Taghizadeh G, Edrese M, Ashrafie M. [Testretest reliability of the Purdue Pegboard test for children with Down syndrome (Persian)]. Koomesh. 2011; 13(1):3543.

[25] Soyupek F, Bolukbafil N, Yorganciolu Z, Gokolu F. The effect of aerobic exercise on hand strength and dexterity of patients with coronary artery disease. Turkish Journal of Physical Medicine and Rehabilitation. 2006; 52:72-75.

[26] Desai K, Kene K, Doshi M, More S, Desai S. Normative data of purdue pegboard on Indian population. The Indian Journal of Occupational Therapy. 2006; 37(3):69-72.

[27] Bear-Lehman J, Abreu BC. Evaluating the hand: issues in reliability and validity. Physical Therapy. 1989; 69(12):1025-33. doi: 10.1093/ptj/69.12.1025

[28] Thompson A, Murphy D, Dell' Acqua F, Ecker C, McAlonan $\mathrm{G}$, Howells $\mathrm{H}$, et al. Impaired communication between the motor and somatosensory homunculus is associated with poor manual dexterity in autism spectrum disorder. Biological Psychiatry. 2017; 81(3):211-9. doi: 10.1016/j.biopsych.2016.06.020

[29] Najafi N, Mokhtari F, Lankarani M, Bagdassarian H. [Correlation of raw conners' scores and family characteristics in general population of primary school children (Persian)]. Annals of Military and Health Sciences Research. 2004; 2(2):327-332.

[30] Salehi B, Moradi S, Ebrahimi S, Rafeei M. [Comparison of ADHD (Attention Deficit Hyperactivity Disorder) prevalence between female and male students of primary schools in Arak City in academic year of 2009-2010 (Persian)]. Scientific Journal of Kurdistan University of Medical Sciences. 2011; 16(2):45-54.

[31] Pastor PN, Reuben CA, Duran CR. Identifying emotional and behavioral problems in children aged 4-17 years: United States, 2001-2007. National Health Statistics Reports. 2012; 24(48):1-17.

[32] Barker DH, Quittner AL, Fink NE, Eisenberg LS, Tobey EA, Niparko JK, et al. Predicting behavior problems in deaf and hearing children: The influences of language, attention, and parent-child communication. Development and Psychopathology. 2009; 21(2):373-5. doi: 10.1017/ s0954579409000212

[33] Whitmorit S, Clark C. Kinaesthetic acuity and fine motor skills in children with attention deficit hyperactivity disorder: a preliminary report. Developmental Medicine and Child Neurology. 2008; 38(12):1091-1098. doi: 10.1111/ j.1469-8749.1996.tb15072.x

[34] Harvey WJ, Reid G. Attention-deficit/hyperactivity disorder: A review of research on movement skill performance and physical fitness. Adapted Physical Activity Quarterly. 2003; 20(1):1-25. doi: 10.1123/apaq.20.1.1
[35] Mirzakhani N, Ashayeri H, Zeraati H, Behnia F. [The effect of fine movements training of hands on drawing and writing skills of slow learner students (Persian)]. Iranian Journal of Psychiatry and Clinical Psychology. 2004; 10(12):85-92.

[36] Jafari Z, Malayeri S, Rezazadeh N, HajiHeydari F. [Static and dynamic balance in congenital severe to profound hearing-impaired children (Persian)]. Bimonthly Audiology-Tehran University of Medical Sciences. 2011; 20(2):102112.

[37] Nazi S, Rahimzadeh-Rahbar S, Karimi H. Comparison of motor skills in boys and girls first grade student in Tehran (Persian)]. Journal of Rehabilitation. 2006; 7(2):37-40.

[38] Sheykh M, Bagherzadeh F, Abd Am, Gholam Ar, Safari M. [A comparison between motor performance \& motor skills in 11-16 year-old students in South Of Tehran (Persian)]. Harakat. 2008; 37:59-75 .

[39] Jafari Z, Karimi H, Sazmand A, Malayeri S. [Comparing the prevalence of handedness between normal and congenitally deaf students in age intervals of 12 to 18 years in Tehran (Persian)]. Journal of Rehabilitation. 2007; 8(1):2534 .

[40] Triggs WJ, Calvanio R, Levine M, Heaton RK, Heilman KM. Predicting hand preference with performance on motor tasks. Cortex. 2000; 36(5):679-89. doi: 10.1016/s00109452(08)70545-8

[41] Butterfield SA. Influence of age, sex, hearing loss, and balance on development of running by deaf children. Perceptual and Motor Skills. 1991; 73(2):624-626. doi: 10.2466/ pms.1991.73.2.624

[42] Amouzadeh Khalili M, Yadegary H. [Comparison of fine motor development in urban and rural nursery school children in Semnan (Persian)]. Koomesh. 2004; 5(1):53-62.

[43] Tsiotra GD, Flouris AD, Koutedakis Y, Faught BE, Nevill AM, Lane AM, et al. A comparison of developmental coordination disorder prevalence rates in Canadian and Greek children. Journal of Adolescent Health. 2006; 39(1):125-7. doi: 10.1016/j.jadohealth.2005.07.011

[44] Walhain F, van Gorp M, Lamur KS, Veeger DHEJ, Ledebt A. Health-related fitness, motor coordination, and physical and sedentary activities of urban and rural children in surname. Journal of Physical Activity and Health. 2016; 13(10):1035-41. doi: 10.1123/jpah.2015-0445

[45] Shahi Y, Mirzamani SM, Afrouz GA, Pourmohammadreztajrishi M, Salehi M. Effect of parents 'educational level on social skills and behaviour problems of students with down syndrome. Quarterly Journal of Fundamentals of Mental Health. 2009; 11(2):141-148.

[46] Bakhtiari S, Shafinia P, Ziaee V. Effect of selected exercises on elementary school third grade girl students' motor development. Asian Journal of Sports Medicine. 2010; 2(1):51-56.

[47] Bernardi F, Boertien D. Non-intact families and diverging educational destinies: A decomposition analysis for Germany, Italy, the United Kingdom and the United States. Social Science Research. 2017; 63:181-91. doi: 10.1016/j. ssresearch.2016.09.004 
[48] Gholamali Lavasani M, Keyvanzadeh M, Keyvan Zadeh $H$. [Relationship between academic activity, emotional intelligence, achievement motivation, contextual variables and academic achievement among high school students (Persian)]. Journal of Psychology and Education. 2007; 37(1):99-123 .

[49] Lin LY, Cherng RJ, Chen YJ. Relationship between time use in physical activity and gross motor performance of preschool children. Australian Occupational Therapy Journal. 2016; 64(1):49-57. doi: 10.1111/1440-1630.12318

[50] Rösblad B, Gard L. The assessment of children with developmental coordination disorders in Sweden: A preliminary investigation of the suitability of the movement ABC. Human Movement Science. 1998; 17(4-5):711-9. doi: 10.1016/s0167-9457(98)00020-7 
July 2016 . Volume 6. Number 2

PHYSICAL TREAT MINTS 